Article

\title{
An Approach to Litter Generation and Littering Practices in a Mexico City Neighborhood
}

\author{
Cecilia E. Muñoz-Cadena ${ }^{1}$, Pedro Lina-Manjarrez ${ }^{1}$, Irma Estrada-Izquierdo ${ }^{2}$ and \\ Eva Ramón-Gallegos ${ }^{2, *}$
}

1 Centro Interdisciplinario de Investigación y Estudios en Medio Ambiente y Desarrollo (CIIEMAD), Instituto Politécnico Nacional, Calle 30 de Junio de 1520 s/n., Barrio La Laguna Ticomán, C.P. 03340, México D.F., Mexico; E-Mail: linapedro@hotmail.com

2 Laboratorio de Citopatología Ambiental, Departamento de Morfología, Escuela Nacional de Ciencias Biológicas del Instituto Politécnico Nacional, Carpio y Plan de Ayala s/n, Col. Plutarco Elías Calles, CP 11340 México D.F., Mexico; E-Mails: lepidochelys@hotmail.com (I.E.-I.); evaramong@yahoo.com.mx (E.R.-G.)

* Author to whom correspondence should be addressed; E-Mail: evaramong@yahoo.com.mx; Tel.: +52-55-5729-6300 (ext. 52399 and 52400); Fax: +52-55-7229-6300.

Received: 17 April 2012; in revised form: 25 June 2012 / Accepted: 26 July 2012 /

Published: 10 August 2012

\begin{abstract}
Urban litter is generated by human societies everywhere. Some litter is recyclable waste. In this study, the acronym RMSW is used to refer to recyclable municipal solid waste generated in streets. Public attitude towards RMSW generation, generators' perceptions, and quantification of RMSW in streets were examined in a Mexico City neighborhood, where litter presence causes major environmental problems affecting the population year after year. Interviews with neighborhood residents and item counts were carried out from 2010 to 2011 . In all, 58\% of interviewees reported generating RMSW at variable frequencies while $42 \%$ said they did not generate this kind of waste. Laziness, lack of vigilance by municipal authorities, no litter bins in streets, and imitation were the main causes identified by interviewees as reasons for littering. Potential litter generators may be of any age, educational level or income. Interviewees' perception of RMSW generation was compared with item counts in the neighborhood studied.
\end{abstract}

Keywords: litter; recyclable waste; attitude; perception; generator 


\section{Introduction}

The presence and accumulation of litter in public spaces is a widely recognized environmental issue in diverse countries because of its impact on different areas, which can be classified as follows: (1) Aesthetic blight, since litter is aesthetically unattractive and its tendency to fly or move about decreases scenic potential and is a public nuisance [1,2]. (2) Health hazard impact, the majority of reported injuries occurring in outside areas are caused by broken glass [1] or pathogens in discarded hypodermic needles. An additional potential health hazard to humans are the rotting contents of bottles, tin cans [2] and wrappers that are scavenged by house pets. (3) The combination of high litter loads and high rainfall plus unreliable maintenance programs frequently blocks sewer systems with the consequent risk of flooding [3]. (4) The presence of litter in public spaces increases refuse collection costs and associated economic losses [4]. The cost imposed by litter on society is reflected by the loss of amenity in having to share streets and parks with litter [5]. (5) Litter, as a part of urban deterioration, affects crime rates in two ways: (a) it visually advertises that residents tolerate violations of the social order and are unlikely to intervene in order to stop crime and disorderly conduct, and (b) residents feel threatened by disorderly elements in the neighborhood environment and retreat inside their homes without building relationships with neighbors or establishing their ownership of public spaces. This situation undermines social control, thus stimulating disorderly conduct and higher crime rates, while neighbors refuse to maintain public spaces, e.g., by picking up litter [6,7].

Mexico ranks tenth in refuse generation at world level, and $25 \%$ of this waste is found in public areas [8]. Mexico City, the nation's capital, produces more than 12,000 tons of refuse daily, 14\% of which is found in public spaces and is responsible for $50 \%$ of the floods occurring annually in this city [9].

According to the Mexico City Water System [10], these floods are caused by the litter thrown by city dwellers in streets. In 2011, the city government spent 1,741 million pesos $(124,000,000$ U.S. dollars) on programs and actions to remove the 2,400 tons of litter generated each month in the city (Figure 1) [10,11].

Figure 1. A diver of the Mexico City stormwater system [12].

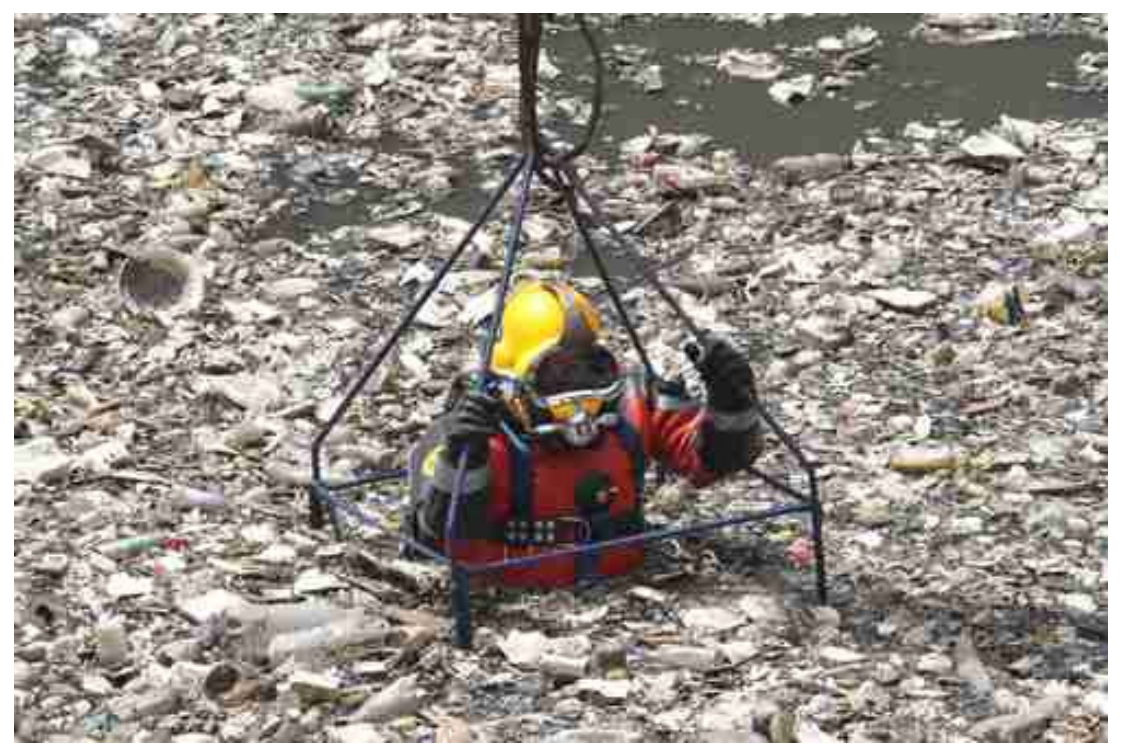


Inadequate disposal and management of solid waste and its impact on human health and the environment have required the establishment of a number of strategies in the Mexico City area. These are defined in a normative framework that allows for more efficient control of environmental pollution as well as the development of policies to reduce litter generation and stimulate the re-use and recycling of waste materials [13,14]. These frameworks include: (1) the Federal District Solid Waste Law (Ley de Residuos Sólidos del Distrito Federal (LRSDF)), which regulates both the integral management of municipal solid waste and the collection and street cleaning services. Article 25 of this law expressly prohibits disposing of any type of waste in public spaces, including the drainage and storm sewer system, as well as creating illegal dumps. It also makes clear that all municipalities (delegaciones) in the city are required to provide and maintain litter bins in streets [15]. (2) Regulations pertaining to the Federal District Solid Waste Law (Reglamento de la Ley de Residuos Sólidos del Distrito Federal (RLRSDF)) seek to prevent and reduce the generation of solid waste, and ensure the co-responsibility of all individuals and public entities through sanctions, fines and penalties [16]. (3) The Federal District Civic Culture Law (Ley de Cultura Cívica del DF $(L C C D F)$ ) ordains the co-responsibility of city residents and authorities in regard to conservation of the urban environment, including streets and public spaces. It includes violations for the failure of owners to collect the feces of animals of their property as well as for littering or the disposal of refuse in public areas $[17,18]$.

However, the vigilance, control and enforcement of environmental regulations for adequate litter management in public spaces are ineffective. Limited sanctions determine the failure of actions by agencies responsible for litter vigilance and control. Also, not all transgressions are sanctioned. Weaknesses have been found in the competence of municipal authorities, who are unable to set up effective judicial actions in relation to technical faults regarding the final disposal, treatment or storage of waste, much less when it comes to those of litter generation in which the generator cannot be identified or the act is not deemed to merit a judicial proceeding [19,20]. The vulnerability of management plans and programs must also be stressed, since these are often put aside upon the arrival of new municipal authorities despite the fact that such projects require lengthy time periods of up to 25 years to mature as well as stable economic and political conditions. This results in technological delays, inefficient services, and corruption [19,21].

Despite these obstacles, the importance of monitoring and diagnosing litter generation and litter volumes in public spaces is evident, both in view of their impact and to determine the environmental load of this waste and the potential costs of its removal. To this end, diverse strategies are used, including weighing the litter, volume estimates, and item counts [22,23]. Even subjective measurements are considered, such as residents' perception as determined by surveys [24,25].

In Mexico City, no study has been conducted on residents' perception of litter generation in public spaces, and studies monitoring litter generation are scarce. Al-Kathib et al. [26] and the U.S. organization Keep America Beautiful (KAB) [27] state that the generation of this type of waste is unique to each region and culture, it being therefore important to study this phenomenon wherever it takes place.

To this end, the Jardín Balbuena neighborhood, located in Venustiano Carranza, one of the 16 municipalities that constitute Mexico City, was proposed for use as the study area. 
This municipality is among the highest in terms of waste generation and illegal dumping, as shown in Figure 2 [28].

Figure 2. Generation of waste in public spaces and illegal dumps in Mexico City.

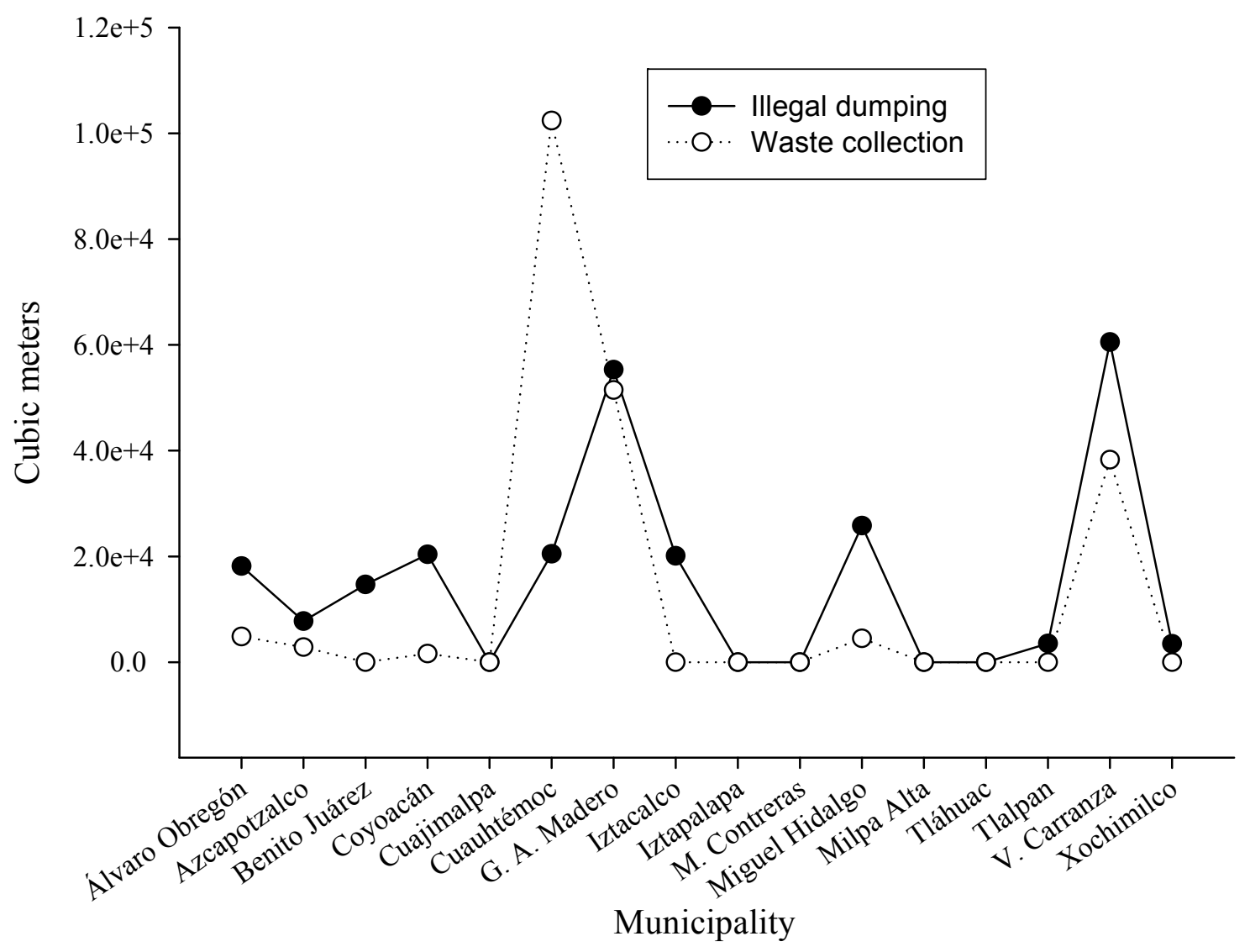

A comparative study of litter generation conducted in 2006 in two neighborhoods of Mexico City with different socioeconomic profiles [29] showed that the higher-profile neighborhood was representative for carrying out a perception study, due to its high levels of litter generation. This higher-profile neighborhood was Jardín Balbuena.

Some litter can be recycled as provided in the LRSDF [15], including items made of paper, certain types of plastic, cardboard, glass or cloth, while the rest, if biodegradable, can be composted. All of these are considered recyclable municipal solid waste (RMSW). Except for items falling within these ranges, litter is considered to be of no utility since Mexico has neither the infrastructure nor the resources necessary to recycle this type of waste.

The initial assumption was to find out whether residents' perception of their neighborhood environment came close to matching reality. Thus, the following goals were proposed for this study:

1. To quantify recyclable urban solid waste (RMSW) in streets of the Jardín Balbuena neighborhood.

2. To identify littering practices and the knowledge and perception of residents of this neighborhood with regard to the generation and impact of recyclable urban solid waste in streets (RMSWS).

The information gathered can be included in the design of future plans and programs for management and control of this type of waste. 


\section{Materials and Methods}

A cross-sectional practices and perception study was conducted among residents of the Jardín Balbuena neighborhood. Additionally, RMSW in streets, such as plastic, paper, cardboard, metal, glass and cloth, was counted immediately before street sweepers passed. These types of waste are classified thus in accordance with federal and local laws due to their nonhazardous, nondegradable and recyclable nature. Cigarette butts were also recorded since they are considered a major litter problem in other countries $[7,30]$.

The Jardín Balbuena neighborhood is part of Venustiano Carranza Municipality, located in east-central Mexico City. It covers a surface area of 3342 ha which represents $2.24 \%$ of the total surface area of Mexico City. According to the 2001-2003 Integrated Territorial Program for Social Development (ITPSD) [31] the neighborhood has 20,706 inhabitants, of which 34\% are 0-15 years old, $44 \%$ are $16-64$ years old and $32 \%$ are 65 years or older. The economically active population, i.e., the fraction of the general population of either gender that is either employed or actively seeking employment for the production of goods and services [32], comprises 11,050 individuals. A total of $61.4 \%$ of adults have had no higher education while $38.39 \%$ have gone beyond the high school level, not only to college or university (including teacher training schools and community colleges) but also to graduate studies. The Jardín Balbuena neighborhood was selected based on preliminary observations which indicated that it was an area of RMSWS generation and had daily street sweeping and truck collection services [16]. The National Institute of Statistics and Geography (INEGI) periodically provides information that can be used to deduce population income through the minimum wage of employed workers. In 2010 the minimum daily wage in Mexico was 57.46 pesos, equivalent to 4.53 U.S. dollars; in 2011 it was 59.82 pesos [33].

\subsection{RMSWS Counting Procedure}

Sampling was performed during seven weeks from December 2010 to February 2011. The number of RMSW items (referred to as frequency in the study) was recorded every day. Information was also collected regarding the type, day of generation and commercial brand (when applicable) of each item, and the type of person who disposed of it.

Six sites were selected for sampling based on a study by Barriada-Pereira [34], the official Mexican norm NMX-AA-061-1985 [35], and the study by Muñoz-Cadena [29] performed in 2006 in the same sites, with a total length of $2,400 \mathrm{~m}$. This resulted in a pre-sample size of 115 households by socioeconomic level with a risk factor of $\alpha=0.05$ from a total of 500 households. The number of households in each of the sampled blocks was 250, which is in compliance with the requirement of 115 households provided in the official Mexican norm. Sampling was done during winter months, a fact influencing litter composition since facial tissue is found in larger quantities due to seasonal illnesses such as the flu and sore throats. Polystyrene foam containers, which keep food and beverages warm, are also more frequent, while the number of cold drink containers is less. 


\subsection{RMSWS Survey Procedure}

The study population - 20,706 inhabitants [31] — and a sample size of 300 questionnaires for a previous survey of randomly chosen residents in the Jardín Balbuena neighborhood were used to determine the sample size for the present study. Surveys were taken in streets as well as schools, shopping centers and meeting places. Children were interviewed after prior consent of their parents and teachers, who were informed in advance. Individuals were randomly selected according to Kerlinger's [36] suggestions for survey taking. The proportion of known generators of RMSW in the previously sampled population was $p=(0.61)$ while that of known non-generators was $q=(0.39)$. These values were substituted for $p$ and $q$ in the formula (Equation (1)).

$$
n=z^{2} p q / e^{2}
$$

where:

$n=$ sample size

$z=$ confidence coefficient

$p=$ probability of occurrence of the event (individuals who are RMSW generators)

$q=$ probability of non-occurrence of the event (individuals who are not RMSW generators) $\mathrm{e}=$ standard error [37].

This resulted in a recommended sample size of 360 questionnaires for the present attitude survey. A total of 633 residents were interviewed, however, thus increasing the validity and reliability of the data obtained.

The questionnaire was initially based on a standard questionnaire by Recena et al. [38], studies by Enkerlin et al. [39] and Al-Khatib et al. [26], and two survey forms presented for businesses and the KAB affiliate in the 1999 Florida Litter Study [40]. All of these were adapted to waste generation in Mexico City streets. The questionnaire was tested and enriched with suggestions from Jardín Balbuena residents and residents of other neighborhoods in the city, including questions regarding RMSW-related perceptions and practices. Both socioeconomic aspects and variables related to interviewees' littering practices and perceptions were covered in the questionnaire, which was divided into four sections. The first section examined residents' perception of the impact of RMSW presence, through two dependent variables: (1) Do you think litter is a problem?; (2) Because it contaminates the soil; air; water; landscape; vegetation; causes health or financial problems. The second section dealt with independent variables related to the socioeconomic characteristics of interviewees: (3) What is your gender?; (4) What is your age group?; (5) Which wage interval, expressed as multiples of the current minimum monthly wage, best represents your family income?; (6) What is your level of studies?. The third section included independent variables with regard to interviewees' personal practices of RMSW generation, their frequency and the type of waste involved: (7) How many times a week do you litter?; (8) What types of litter do you throw in the street?. Finally, the fourth and last section dealt with residents' perceptions of RMSW generators, which were used as dependent variables: (9) Why do people litter in the street?; (10) How would you describe your street cleaning service?; (11) Do you perceive there is more litter on some days of the week than on others?; (12) Do you believe that some commercial brands are more commonly represented in street litter?; (13) Do you have any suggestions for solving or reducing the litter problem?; (14) Which gender 
generates more litter?; (15) What is the approximate age of stronger litter generators?; (16) What level of studies do stronger litter generators have?; (17) What is the socioeconomic level of stronger litter generators?

Questions were asked in this order because people in Mexico City are reluctant to provide personal information due to public perception of insecurity. Informed consent was obtained from all participants, who received appropriate ethical considerations. Interviewing took place from June 2010 to June 2011.

\subsection{Statistics}

Comparison of sizes among RMSW items was performed with the Mann-Whitney U test; the type, the size of waste and whether the waste was branded or not were compared by analysis of variance (ANOVA) and a post-hoc Tukey test was used to find any significant differences. Chi-square tests were applied to determine potential relationships among categorical variables. In all cases, differences were considered significant at $p \leq 0.05$. Yates' correction for continuity was also used. All tests were performed with Sigma Stat v2.03 for Windows (Jandel Scientific, San Rafael, CA, USA).

\section{Results}

\subsection{Profile of the Study Population}

A total of 633 residents from the Jardín Balbuena neighborhood were interviewed. Their general profile is shown in Table 1; $49 \%$ of them were male and $51 \%$ were female. The average age was $35.2 \pm 15.2$ years. Approximately half of the interviewees had university or graduate school studies (52\%) and only $1 \%$ had never attended school. According to the monthly income reported by the employed workers interviewed, most of them earned more than five times the minimum monthly wage (48\%) while $17 \%$ received no salary.

Table 1. Social and demographic characteristics of Jardín Balbuena residents.

\begin{tabular}{lccc}
\hline & General population $^{\mathbf{a}}$ & & Interviewees \\
\cline { 1 - 1 } Characteristics & Number of individuals (\%) $^{\text {Gender }}$ & & Number of individuals (\%) \\
\hline Males & $10,901(44.6)$ & $309(49)$ \\
Females & $13,581(55.4)$ & $325(51)$ \\
\hline Age (years) & $3,541(14.4)$ & $64(10)$ \\
\hline $0-12$ & $2,877(11.7)$ & $108(17)$ \\
$13-20$ & $6,221(25.3)$ & $151(24)$ \\
$21-30$ & $5,164(21.0)$ & $140(22)$ \\
$31-40$ & $2,287(9.3)$ & $85(13)$ \\
$41-50$ & $257(1)$ & $31(5)$ \\
$51-60$ & $4,243(17.3)$ & $55(9)$ \\
$>61$ & &
\end{tabular}


Table 1. Cont.

\begin{tabular}{|c|c|c|}
\hline \multicolumn{2}{|c|}{ General population $^{\text {a }}$} & \multirow{2}{*}{$\begin{array}{c}\text { Interviewees } \\
\text { Number of individuals }(\%)\end{array}$} \\
\hline Characteristics & Number of individuals (\%) & \\
\hline \multicolumn{3}{|l|}{ Education } \\
\hline None & $224(1.3)$ & $7(1)$ \\
\hline Elementary & $1851(10.4)$ & $80(13)$ \\
\hline Middle school & $2573(14.6)$ & $64(10)$ \\
\hline High school & $5776(32.8)$ & $151(24)$ \\
\hline College or university & $7203(40.9)$ & $255(40)$ \\
\hline Graduate studies & - & $77(12)$ \\
\hline \multicolumn{3}{|l|}{ Income } \\
\hline None & $1167(10.2)$ & $105(17)$ \\
\hline$<1$ mmwpw $^{*}$ & $550(4.8)$ & $39(6)$ \\
\hline 1 to 2 mmwpw * & $1665(14.5)$ & $76(12)$ \\
\hline 2 to 5 mmwpw * & $4312(37.5)$ & $106(17)$ \\
\hline$>5$ mmwpw $*$ & $3793(33.0)$ & $308(48)$ \\
\hline
\end{tabular}

* Monthly minimum wage per worker (mmwpw). The daily minimum wage in Mexico in 2010 was 57,46 pesos, equivalent to 4,53 U.S. dollars; ${ }^{\mathrm{a}}$ Source: [41].

\subsection{Littering Practices and Public Perception of RMSW Generation in Streets}

\subsubsection{Jardín Balbuena Residents}

All interviewees considered RMSW in streets to be a problem for the urban environment. The perceived potential risk of RMSW to humans and the environment is shown in Table 2. A large majority of the residents considered RMSW harmful to human health primarily (21\%), while the rest indicated various environmental aspects such as soil (16\%), air (16\%), water (16\%), vegetation (13\%) and the urban landscape (12\%). Only a few of them (7\%) thought that RMSWS was related to municipal financial problems.

Table 2. Potential risk of recyclable urban solid waste (RMSW) to humans and the environment.

\begin{tabular}{lc}
\hline Considerations & Number of respondents (\%) ${ }^{\mathbf{a}}$ \\
\hline RMSWS is a problem & $634(100)$ \\
RMSWS is harmful to & \\
Human health & $575(20.9)$ \\
Soil & $439(16.0)$ \\
Air & $434(15.8)$ \\
Water & $431(15.7)$ \\
Vegetation & $353(12.9)$ \\
Urban landscape & $327(11.9)$ \\
Municipal finances & $186(6.8)$ \\
\hline
\end{tabular}

\footnotetext{
${ }^{a}$ More than one option was chosen by each respondent. Recyclable urban solid waste in streets (RMSWS).
} 


\subsubsection{Littering Practices and Public Perception of RMSW Generation in Jardín Balbuena Streets}

Table 3 summarizes the practices with regard to RMSWS generation by Jardín Balbuena residents included in the survey. More than half of the interviewees (56.7\%) expressed they produced RMSW at variable frequency rates (always, often, or sometimes). Most of them said they generated this type of litter sometimes (47.9\%). In most cases, the type of RMSW disposed of in streets by interviewees was food or beverage-related (43.5\%). Next were cigarette butts $(21 \%)$, followed by food-related (19.8\%) and beverage-related (10.9\%) items disposed of separately.

Table 3. Jardín Balbuena residents' practices with regard to RMSW generation.

\begin{tabular}{lc}
\hline Frequency of RMSWS generation & Number of respondents (\%) $^{\mathbf{a}, \mathbf{b}}$ \\
\hline Always & $23(3.6)$ \\
Often & $33(5.2)$ \\
Sometimes & $304(47.9)$ \\
Never & $274(43.2)$ \\
${ }^{a}$ Type of RMSWS generated & \\
Food-related & $98(19.8)$ \\
Beverage-related & $54(10.9)$ \\
Both food and beverage-related & $216(43.5)$ \\
Cigarette butts & $104(21.0)$ \\
Others & $24(4.8)$ \\
\hline
\end{tabular}

${ }^{\mathrm{a}}$ More than one option was chosen by each respondent; ${ }^{\mathrm{b}}$ Some interviewees did not answer.

Jardín Balbuena residents' perception of RMSW production in neighborhood streets and its generation by other individuals is shown in Table 4. Most respondents cited laziness as the main cause of RMSW generation (31.8\%), followed by lack of vigilance by municipal authorities (23.1\%), absence of waste receptacles in streets (18.5\%), imitation (13.7\%), etc. Littering without being aware of doing so $(1.9 \%)$ and paying for waste removal through taxes $(1.1 \%)$ were the options receiving the least support.

Table 4. Public perception of RMSW generation.

\begin{tabular}{lc}
\hline Perception of RMSWS generation & ${\text { Number of respondents }(\mathbf{\%})^{\mathbf{a}, \mathbf{b}}}$ \\
Reason for RMSWS production $^{\mathrm{a}}$ & \\
Laziness $^{\text {No vigilance }}$ & $496(31.8)$ \\
No litter bins & $360(23.1)$ \\
Imitation & $289(18.5)$ \\
Ignorance & $214(13.7)$ \\
Irresponsibility & $106(6.8)$ \\
Done without being aware & $47(3.0)$ \\
Paying for waste removal through taxes & $29(1.9)$ \\
\hline
\end{tabular}


Table 4. Cont.

\begin{tabular}{|c|c|}
\hline Perception of RMSWS generation & Number of respondents $(\%)^{\mathrm{a}, \mathrm{b}}$ \\
\hline \multicolumn{2}{|l|}{ Days of higher production of RMSWS ${ }^{a}$} \\
\hline Monday & $156(19.1)$ \\
\hline Tuesday & $59(7.2)$ \\
\hline Wednesday & $65(7.9)$ \\
\hline Thursday & $69(8.4)$ \\
\hline Friday & $112(13.7)$ \\
\hline Saturday & $186(22.7)$ \\
\hline Sunday & $171(20.9)$ \\
\hline \multicolumn{2}{|l|}{ Efficiency of the street cleaning service ${ }^{b}$} \\
\hline Good & $100(33.1)$ \\
\hline Average & $165(54.6)$ \\
\hline $\mathrm{Bad}$ & $37(12.3)$ \\
\hline \multicolumn{2}{|l|}{ Commercial brands ${ }^{\mathrm{a}}$} \\
\hline Coca-Cola (FEMSA) & $214(33.0)$ \\
\hline Sabritas (PepsiCo) & $198(30.6)$ \\
\hline Bimbo (Bimbo Group) & $109(16.8)$ \\
\hline Holanda (Unilever) & $67(10.3)$ \\
\hline Barcel (Bimbo Group) & $60(9.3)$ \\
\hline \multicolumn{2}{|l|}{ Gender of other generators ${ }^{\text {a }}$} \\
\hline Male & $277(71.4)$ \\
\hline Female & $111(28.6)$ \\
\hline \multicolumn{2}{|l|}{ Age of other generators (years) ${ }^{a}$} \\
\hline$<10$ & $106(12.3)$ \\
\hline $11-20$ & $190(22.0)$ \\
\hline $21-30$ & $175(20.2)$ \\
\hline $31-40$ & $146(16.9)$ \\
\hline $41-50$ & $87(10.1)$ \\
\hline $51-60$ & $83(9.6)$ \\
\hline$>61$ & $78(9.0)$ \\
\hline \multicolumn{2}{|l|}{ Educational level of other generators ${ }^{a}$} \\
\hline None & $117(13.3)$ \\
\hline Elementary & $176(19.9)$ \\
\hline Middle school & $178(20.2)$ \\
\hline High school & $200(22.7)$ \\
\hline College or university & $128(14.5)$ \\
\hline Graduate studies & $84(9.5)$ \\
\hline \multicolumn{2}{|c|}{ Socioeconomic level of other generators ${ }^{a}$} \\
\hline Low & $154(30.1)$ \\
\hline Middle & $231(45.2)$ \\
\hline High & $126(24.7)$ \\
\hline
\end{tabular}

${ }^{\mathrm{a}}$ More than one option was chosen by each respondent; ${ }^{\mathrm{b}}$ Some interviewees did not answer.

According to residents' perception, the days of the week when more RMSW is produced are Saturday (22.7\%), Sunday (20.9\%) and Monday (19.1\%). Interviewees' opinion with regard to the 
efficiency of the street cleaning service was divided: half of them $(54.6 \%)$ considered it was average while the rest thought it was either good (33.1\%) or bad $(12.3 \%)$. As regards the commercial brands most frequently found in RMSW in streets, interviewees said that Coca-Cola plastic bottles (FEMSA) were the most common item (33.0\%), followed by plastic wrappers of the following: Sabritas snack foods (PepsiCo, 30.6\%), Bimbo sliced bread and pastry products (Bimbo Group, 16.8\%), Holanda ice cream products (Unilever, 10.3\%) and Barcel snack foods (Bimbo Group, 9.3\%).

The majority of the interviewees indicated their belief that most generators of RMSW in streets were males $(71.4 \%)$ in the 11 to 30 years age groups (42.2\%). Also, respondents believed that the level of studies of most RMSW generators was elementary to high school (62.8\%). The socioeconomic level of other litter generators was thought to be, in ranking order: middle (45.2\%), low (30.1\%) and high $(24.7 \%)$.

\subsection{Total Waste in Streets of the Jardin Balbuena Neighborhood (December 2010-February 2011)}

The total number of RMSW items of any type quantified in Jardín Balbuena streets over a period of 35 days was 12,747. Cigarette butts comprised an additional 1720 items (11.9\%). Among RMSW items, paper $(44.6 \%)$ and plastic $(38.8 \%)$ were the most frequent materials, followed by cardboard $(2.9 \%)$, metal $(0.9 \%)$, glass $(0.6 \%)$ and cloth $(0.3 \%)$.

RMSW items were classified by size — small or large — based on the MGM Management classification [42]. A significant difference was found between these sizes. Small items were more common than large ones $(p=0.001)$. Small items comprised $78 \%$ of all RMSWS and large items only $22 \%$.

Comparison of the cumulative daily production of RMSW showed no significant difference among days of the week $(p=0.647)$. Approximately the same amount of litter was produced on any one day.

As regards branded RMSW, the most frequently found items were plastic waste from the following companies: (1) PepsiCo Sabritas wrappers (31\%); (2) Bimbo Group wrappers (20\%); (3) FEMSA Coca-Cola plastic bottles (15\%); (4) wrappers of BonIce frozen bars (BonIce, 6\%); (5) Unilever Holanda wrappers (4\%); and plastic bottles of: (6) Bonafont drinking water (Danone, 3\%); (7) PepsiCo Pepsi-Cola (3\%); (8) Dan-up yoghurt drinks (Danone, 2\%); and (9) Peñafiel mineral water beverages (Cadbury-Schweppes, 1\%). The remaining 14\% was shared among different commercial brands. A significant difference among commercial brands was found in this analysis $(p=0.001)$.

In addition, individuals generating RMSW were recorded. Results show a significant difference between males and females $(p=0.009)$. Men produced more litter than women, but there was no difference in terms of age group between both genders $(p=0.558)$.

\subsection{Relations between Item Counts and Littering Practices and Perception of RMSW}

Some socioeconomic factors have been traditionally related to urban solid waste generation including educational level, income, and population density $[43,44]$. Despite the high risk involved in attempting to establish a correlation between residents' perception of RMSW and actual conditions in the neighborhood environment, it was decided to use Chi-square tests as a means to determine if any potential relationship existed between the data obtained from item counts and the frequency of responses to survey questions. Table 5 shows the results of these tests. 
When the daily generation of RMSW items was compared with interviewees' perceptions by means of a Chi-square test, a significant relationship $(p=0.001)$ was found for every day of the week except Fridays. As regards the relationships between perceived and counted branded RMSW items, only Coca-Cola waste showed a significant relationship $(p=0.001)$ between item counts and interviewees' perception. Despite the fact that Sabritas and Bimbo wrappers were the most common items found in streets (31\% and 20\%, respectively), neighborhood residents did not perceive them as such.

Most interviewees expressed the belief that men generated more street litter $(71.4 \%)$, and they were right: male percentages were higher in litter counts $(80.6 \%)$. As regards the age of litter generators, interviewees' perception (12.3\%) was related only with the group of individuals less than 10 years old $(p=0.001)$.

Table 5. Relationship of residents' perception and actual RMSW numbers '

\begin{tabular}{lccc}
\hline Factors & Item counts & Respondents & \\
\hline Day of the week & & & \\
\hline Monday & 2011 & 156 & $p=0.001^{\mathrm{a}}$ \\
Tuesday & 1924 & 59 & $p=0.001^{\mathrm{a}}$ \\
Wednesday & 2112 & 65 & $p=0.001^{\mathrm{a}}$ \\
Thursday & 2112 & 69 & $p=0.001^{\mathrm{a}}$ \\
Friday & 1895 & 112 & $p=0.663$ \\
Saturday & 2257 & 186 & $p=0.001^{\mathrm{a}}$ \\
Sunday & 2156 & 171 & $p=0.001^{\mathrm{a}}$ \\
\hline Commercial brands & & & \\
\hline Sabritas wrappers & $4485(31)$ & $198(31)$ & $p=0.844$ \\
Bimbo wrappers & $2893(20)$ & $109(17)$ & $p=0.053$ \\
Coca-Cola plastic bottles & $2170(15)$ & $214(33)$ & $p=0.001^{\mathrm{a}}$ \\
\hline Gender of generators & & & $p=0.001^{\mathrm{a}}$ \\
\hline Males & 29 & 277 & $p=0.770$ \\
Females & 7 & 111 & \\
\hline Age of generators & & & $p=0.001^{\mathrm{a}}$ \\
\hline$<10$ & 10 & 106 & $p=0.583$ \\
$11-20$ & 6 & 190 & $p=0.472$ \\
$21-30$ & 5 & 175 & $p=0.808$ \\
$31-40$ & 5 & 146 & $p=0.957$ \\
$41-50$ & 3 & 87 & $p=0.573$ \\
$51-60$ & 5 & 83 & $p=0.677$ \\
$>60$ & 2 & 78 & \\
\hline & 5 & & \\
\hline
\end{tabular}

${ }^{\mathrm{a}}$ Significant relationship ( $p \leq 0.05$, Chi-square).

\section{Discussion}

\subsection{Profile of the Study Population}

The proportions expressed in the interviews are in general agreement with the percentages mentioned in the 2001-2003 ITPSD [45] for the general population in Jardín Balbuena. The percentage of female residents in the neighborhood was $55.23 \%$, while slightly more than half of the interviewees 
were women (51\%). The average age of interviewees was $35.2 \pm 15.2$ while the average age of neighborhood residents according to the ITPSD was 35 years. The prevailing educational level among interviewees was college or university $(52 \%)$, i.e., 15 or more years of schooling. The ITPSD stipulates 11.7 years as the educational average, i.e., high school level. According to interviewees, $48 \%$ of them had an income five times or more the minimum monthly wage, while the ITPSD Program states that this is the case for $38.71 \%$ of residents. The Jardín Balbuena population displays an aging tendency. The Venustiano Carranza urban development program [46] states that the neighborhood has not been repopulated with younger people. Thus, since the average age of residents is 35 years and most of them have a fairly high level of studies, family income must consequently also be generally high by Mexico City standards.

\subsection{Littering Practices and Public Perception of RMSW Generation in Streets}

\subsubsection{Jardín Balbuena Residents}

Remarkably, although all interviewees expressed that RMSW had a negative impact on the urban environment, they linked this impact primarily to human health problems $(21 \%)$. The dynamics of RMSW in streets involves not so much the accumulation of this waste but its dispersal. Its negative impact is mostly due to its association with the organic waste present in streets such as food remains in discarded containers, or dog feces. Due to the very nature of the materials from which it is made, RMSW can shelter pathogens or disease vectors and allow their proliferation. This phenomenon is described by Rosas et al. [47], who collected aerobiological samples in diverse Mexico City solid waste management plants. Pathogenic bacteria counts were higher in waste selection, treatment and recovery plants where organic waste is mixed with inorganic waste items such as plastic bottles, paper or plastic bags and wrappers, etc. [48].

\subsubsection{Littering Practices and Public Perception}

Practices of RMSW generation reflect consumer preferences in terms of the frequency and types of waste produced. However, a paradoxical behavior exists since despite their belief of the negative impact of litter $(100 \%)$, over half of the interviewees admitted generating such waste $(56.7 \%)$. This may be related to Torgler and García-Valiñas' [49] idea that the current prevalence of environment-related social norms influences the cooperative behavior of individuals, who may therefore state their full agreement towards considering that the presence and accumulation of RMSW has a negative impact on the environment. However, if these social norms are not observed, the consequences for the generator may be negative, it being difficult therefore to honestly admit that one's behavior is not in accord with societal expectations [50].

On the other hand, according to the OECD [51] this is associated with the negative externalities of each individual, who does not take into account, at the time he/she decides to generate RMSW, either the quantity of what he/she consumes or the items consumed. The external costs of waste generation, e.g., those affecting the soil and air, are ignored by the general public, a fact that tends to increase the amount of RMSW generated. 
The perception of most Jardín Balbuena interviewees (31.8\%) is that laziness is the main cause of RMSW generation in streets, followed by lack of vigilance $(23.1 \%)$ and no litter bins (18.5\%). These results are comparable with those provided by a review of litter-related literature which says that laziness, no nearby bins and habit are the main causes for littering [50,52]. This perception is consistent with statements obtained in Australia regarding the most common reasons for littering: "too lazy" (24\%), "no ashtray" (23\%) and "no bin" $(21 \%)[53,54]$.

Although only $13.7 \%$ of the interviewees mentioned imitation as the main cause of RMSW generation, their preference for this option is consistent with Mercado's [55] proposal that, through language, human beings know what happens in their structured world. People learn the explanations for what is and what should be, but the messages received are not accepted without limitation. Since human communication is highly structured, individuals reject or accept the messages received from others whom they consider worthy of imitation. People take their standards, beliefs and values from these models. This may be so in the case of littering behavior. Some researchers have found that littering, like vandalism, is contagious. Several studies in the litter-related literature suggest that littering is more likely to occur in areas where litter is already present than in litter-free areas [6,56].

A total of $18.5 \%$ of the interviewees mentioned the absence of litter bins in streets as a reason for littering. Littering has also been shown to decrease if conveniently located waste receptacles are available. Researchers suggest that a nearby receptacle catches a person's attention and, once people are aware of this option, they are more likely to "do the right thing". However, a study by Curlow [54] in Australia showed that lack of litter bins is not a determinant factor for litter generation.

According to residents' perception, the days of the week when more RMSW is produced are Saturday through Monday. If these results are compared with actual data, a significant relationship is found for all days of the week except Fridays. A possible explanation for this may be the fact that people consider Friday evening a part of the weekend, and are prone to believe that during these rest days people stay at home or close to home, with a potential consequent increase of RMSW generation in nearby public spaces [29], which remains untouched by cleaning services through Monday morning. Nevertheless, present results in this regard differ from those obtained in the same neighborhood in 2006, when the period showing a significant difference in RMSWS generation was Friday through Sunday [29].

Interviewees' perception of the presence of major commercial brands in street litter, such as Sabritas (PepsiCo), Coca-Cola (FEMSA) and Bimbo (Bimbo Group), is probably a result of market presence. Most relationships between perceived and counted commercial brands in RMSW were significant $(p=0.001)$, with the exception of Sabritas wrappers which were the most frequent item found in streets (31\%). Consumer product advertising in Mexico is associated with a small number of strong brands, such as those found in the present study. It was therefore of interest to determine residents' perception of these brands as a potential cause of environmental impact despite the positive publicity they receive [57]. The analysis of commercial brands in RMSW and residents' perception of them aimed to ascertain the co-responsibility of commercial firms for environmental impact caused by their products.

Most interviewees expressed the belief that men generate more litter in streets and this idea was supported by actual data. Nevertheless, a study undertaken in 1968 for KAB found that male and female littering rates were similar [27]. As regards the age of litter generators, 
respondents' perception (12.3\%) was related only to the age group 10 years or younger $(p=0.001)$. Most studies involving subjects of various ages have found that younger people litter more than older individuals. Researchers suggest that younger people are less affected by societal norms and are less afraid of negative consequences [20].

A majority of the interviewees rated the efficiency of the street cleaning service as average (62.8\%). However, Acurio et al. [21] state that the amount of solid waste removed by street sweeping increases through the addition of domestic or household refuse if truck collection services are inefficient or inadequate. This is evident in the types of RMSW found in streets during the 2010-2011 counting period. In general, there was no waste typical of domestic consumption, such as cooking oil plastic bottles, milk cartons, cleaning product containers, etc., except for plastic bags left in the street with household refuse. This suggests that waste derived from slow-consumption items destined mostly for household use increases as soon as the regular truck collection service is unable to handle it efficiently. Residents must then make use of other means to get rid of their refuse and, as a result, the street cleaning service becomes less efficient [58,59].

\subsection{Total Waste Items in Streets of the Jardin Balbuena Neighborhood}

The total number of RMSW items found in six sampling sites in Jardín Balbuena with a total length of $2400 \mathrm{~m}$ during 39 days from December 2010 to February 2011 was 10,711. Comparatively, in 2006, 12,595 RMSW items were generated over 35 days from August to November in these same six sampling sites [34]. This indicates a 15\% reduction in RMSW generation, which is probably due, not to any improvement in waste management since conditions have not changed, but to the current economic crisis [13]. The quality of the municipal solid waste generated is known to be correlated with the economic situation of a country [21,59].

Cigarette butts were counted in Jardín Balbuena for purposes of comparison with a litter audit carried out in Toronto, Canada, in 2006, which regarded cigarette butts as organic waste. This audit sampled 298 sites with a total length of 18,166 m between July 14 and August 11 [42], while during the same year 12 sites with a total length of $4800 \mathrm{~m}$ were sampled in Mexico City. Results showed total counts of 10,581 items (Toronto) and 22,105 items (Mexico City) [26], indicating high levels of generation of this type of waste in both these cities.

\subsection{Relationship of Littering Practices and Public Perception of Actual RMSW Generation in Streets}

It is generally accepted that a direct relationship exists between household income and litter generation $[21,43,60]$. In view of this, working-age people with a high level of studies (college or university) and well-paid jobs might be thought to litter more. However, results of the present study show that there is no pattern defining stronger RMSW generators: they may be of any age, educational level or socioeconomic status.

This may be due to the fact that working-age individuals, as evidenced by people of the average neighborhood age in the study, share their income with younger people (i.e., their children) as well as older people (i.e., their parents). This is so because Jardín Balbuena residents are mostly older individuals who bought homes in the area when they were young adults. The neighborhood is part of the Venustiano Carranza Municipality, one of the three least populated Mexico City municipalities, 
which is otherwise densely populated. Living in Jardín Balbuena is much appreciated due to its relatively high real estate values, centric location, and the fact that the original population is getting older and dying, making room for younger people. All these factors contribute to make working-age people come back to live with their parents [46,61]. These working-age individuals are also of reproductive age and are likely to have children who benefit from their parents' income, thus increasing the probability of finding litter generators in the neighborhood.

The different types of RMSW quantified in streets of the Jardín Balbuena neighborhood all showed a significant relationship with littering practices mentioned in regard to these items during the survey. Similarly, littering practices and different socioeconomic factors such as age group, educational level and family income were significantly related, indicating that any individual regardless of age, level of studies or family income is a potential generator of RMSW in streets, with a slightly lower probability in higher income cases. People also believe that everyone else but themselves is a litter generator. Field research shows that a broad variety of persons contribute to litter generation [42]. The types of RMSW referred to in the survey (food-related items, beverage-related items, both food and beverage-related items, cigarette butts, etc.) indicate that interviewees probably spend on food, beverages and/or a smoking habit according to their own financial capacity. Personal opinions as to what constitutes litter are considerably different from the truth. The public perception is that specific groups of products make up the majority of street litter [42].

\section{Conclusions and Recommendations}

For decades, polluting practices in Mexico City have deteriorated the quality of life of its inhabitants. With the building of environmental awareness and the coming into force of environmental regulations this situation has slowly and gradually changed, but there is still a need to maintain effective environmental vigilance and control policies. Mexico City municipalities and neighborhoods currently show a complex collection of unresolved urban problems.

One of these problems involves an area shared by all city residents - the streets — which constitute a major part of urban public spaces. The amount of public space per inhabitant in Mexico City is $5.4 \mathrm{~m}^{2}$ per inhabitant, well below the 9 to $16 \mathrm{~m}^{2} /$ inhabitant recommended by the World Health Organization.

The problem, however, is not merely one of shortage of public space. It also involves the significant levels of environmental deterioration and pollution sustained by public spaces and the consequent impact of such factors on these areas. Seeking to reverse this situation, the information obtained in the present study may contribute substantially to the projects proposed by the Mexico City Environmental Agenda for the recovery of public spaces [62], including among others:

- Adopt a green area. This program promotes the adoption by individuals or private enterprises of a particular green area space for purposes of care and maintenance, as provided by the regulations in force and in coordination with municipal authorities. Depending on the area adopted, the corresponding individuals or private enterprises are allowed to put up a small sign with the company logo and name.

- Environmental improvement of urban public spaces. This involves summoning specialists from among the general public to submit projects for the environmental improvement and recovery 
of public spaces and streets, under sustainability criteria based on attitude and behavioral studies of the users of such places.

- Awareness programs in schools. Schools are basic places for carrying out activities of environmental education in relation to adequate solid waste management, which can be enhanced with the information obtained in the present study, thus ensuring a multiplier effect reaching into the family home.

- Ongoing training of personnel taking part in sanitation actions by the Mexico City government.

Attitudes and perceptions towards RMSW generation in Jardín Balbuena streets indicate a high probability that residents produce this kind of waste. Although neighborhood residents recognize the potential risk of RMSW to human health and the environment, transforming these perceptions into practical actions that result in lower levels of litter generation may prove a complex task.

More than half of the persons interviewed (56.7\%) admitted being RMSWS generators, and laziness was considered the main cause of RMSW generation, although lack of vigilance and absence of litter bins were also perceived as major causes. Both genders are equally capable of RMSW production in streets but the public perception is that men litter more often. Young people litter more frequently and are also perceived to do so. Respondents' perception of branded RMSW items in streets comes close to actual data from item counts, which may indicate the co-responsibility of commercial firms for environmental impacts originating in their products.

Residents' perception towards RMSW generation and management in neighborhood streets should be taken into account in any sustainable urban waste management program.

The usefulness of surveys extends not only to the evaluation of current conditions but also to prediction of future trends. Frequent ongoing surveys are thus mainstays of a successful solid waste management program.

Educational and technical support that takes into account both cultural and socioeconomic aspects of the population is required in order to change the scenario observed in the present study. In addition, government actions such as littering interdiction and/or restriction, and enforcement of good civic practices, including the provision of a sufficient number of litter bins, are necessary in order to reduce generation of RMSW in streets. Litter bins should be capable of holding larger amounts of inorganic waste (non-biodegradable items made from recyclable or reusable materials) rather than organic (biodegradable) waste. Separate bins must be provided to receive mainly paper, plastic and metal items.

Educational needs and concrete actions for participation in taking care of the environment are a responsibility at all levels, including government and private enterprise participation through economic policies and public involvement. Active participation is required, based on personal awareness motivated by reflection on the persistent impact of human behavior and habits on the environment. If we perceive ourselves as genuine generators of change, we can then see ourselves as real agents acting from an individual level of education to a societal one. Education is forged day by day.

Combined information and action are essential, since a change in our personal perception is generated if we feel we are involved in effecting positive environmental change. Waste and its management offer an opportunity to educate all family members in a way that can reflect our naturalistic intelligence and culture. The persons in charge of educational programs (authorities, waste managers, professors, teachers, students and parents) play an essential role in environmental care. 
Individual perception and personal motivation involve us in effecting environmental change. The capacity and creativity provided by daily teamwork create a synergetic effect against harmful future actions. Since litter generation provides a disagreeable perception of ourselves, taking pertinent actions such as educational feedback to offset this situation allows us to better manage this type of waste and improve our urban environment. We should bear in mind that active involvement and permanent commitment will lead us to a new way of coexisting with our environment.

\section{Acknowledgments}

The authors are grateful to Grupo de la Licenciatura de Servicio de Social de la UNAM, the Centro Escolar Martinique, Rosa María Lara López, Leticia Avelino Rojas in the Iztacalco municipal administration, María Rosales Hernández of Foro Permanente de Mujeres, Miguel Ángel Méndez G., and Diana Santamaría for their support of this study.

\section{Conflict of Interest}

The authors declare no conflict of interest.

\section{References}

1. Arafat, H.A.; Al-Kathhib, I.A.; Daoud, R.; Shwahneh, H. Influence of socio-economic factors on street litter generation in the Middle East: Effects of education level, age, and type of residence. Waste Manag. Resour. 2007, 25, 363-370.

2. Armitage, N.; Rooseboom, A. The removal of urban litter from stormwater conduits and streams: Paper 1-The quantities involved and catchment litter management options. Water SA 2000, 26, $181-188$.

3. Raffoul, L.; Mahon, R.; Goodridge, R. Roadside Litter in Barbados: Sources and Solutions; Centre for Resource Management and Environmental Studies (CERMES), University of the West Indies, Faculty of Pure and Applied Sciences, Cave Hill Campus: Bridgetown, Barbados, 2006; p. 65.

4. Kayhanian, M.; Stransky, C.; Bay, S.; Lau, S.L.; Stenstorm, M.K. Toxicity of urban highway runoff with respect to storm duration. Sci. Total Environ. 2008, 389, 386-406.

5. Brisson, I. Packaging waste and the environment: Economics and policy. Resour. Conserv. Recycl. 1993, 8, 183-292.

6. Ellickson, R.C. Controlling Chronic Missconduct in City Spaces: Of Panhandlers, Skid Roads and Public Space Zoning; Yale Law School Legal Scholarship Repository, Faculty Scholarship Series Paper 408; Yale Law School: New Haven, USA, 1996.

7. Defra. Litter - Organising a clean up. Keep Britain Tidy. Available online: http://www.encams.org (accessed on 8 June 2012).

8. Moctezuma, V.A. Los mexicanos producimos 30 millones de toneladas de basura al año. 2012. Crónicas de la ciudad de México. 2012, Desde Aguascalientes, S.A. de C.V. Available online: http://www.desdelared.com.mx/noticias/2012/2-opinion/0604-albino-0706141224.html (accessed on 6 July 2012). 
9. SPC-DF. Campaña: $50 \%$ de las inundaciones son provocadas por la basura. Secretaría de Protección Civil del Distrito Federal. 2010. México, Distrito Federal. Available online: http://www.proteccioncivil.df.gob.mx/ (accessed on 13 January 2010).

10. SACM. Informa de la extracción de azolve de la infraestructura hidráulica del Distrito Federal. Periodo 2005-2009. Sistema de Aguas de la Ciudad de México; Dirección de Drenaje, Tratamiento y Reúso, Info-DF: Mexico City, Mexico, 2010.

11. Chilanguía. La Basura, Enemigo Número uno en Época de Lluvias. La ciudad de la cultura; Secretaría de Cultura del DF, Secretaría de Finanzas: Mexico City, Mexico, Agosto 2011; p. 129.

12. Ap. Más de 10,000 familias viven en situación crítica de riesgo, afirman diputados. La Jornada, 23 July 2010.

13. OECD. OECD Key Environmental Indicators; Organization for Economic Cooperation and Development (OECD): Paris, France, 2004; p. 38.

14. OPS. Evaluación Regional de los Servicios de Manejo de Residuos Sólidos Municipales en México; Organización Panamericana de la Salud: Mexico City, Mexico, 2003.

15. LRSDF. Ley de Residuos Sólidos del Distrito Federal; Gaceta Oficial del DF: Mexico City, Mexico, 2003.

16. RLRSDF. Reglamento de la Ley de Residuos Sólidos del Distrito Federal; Gaceta Oficial del Distrito Federal: Mexico City, Mexico, 2008.

17. Ley de Cultura Cívica del Distrito Federal; Gaceta Oficial del Distrito Federal: Mexico City, Mexico, 2004.

18. RLCCDF. Reglamento de la Ley de Cultura Cívica del Distrito Federal; Gaceta Oficial del Distrito Federal: Mexico City, Mexico, 2004.

19. GTZ. Guía en elaboración de Planes Maestros para la Gestión Integral de Residuos Sólidos Municipales en el Estado de México; Agencia de Cooperación Técnica Alemana (GTZ) and Comisión Mexicana de Infraestructura Ambiental: Mexico City, Mexico, 2003. Available online: http://www2.gtz.de/dokumente/bib/07-0128.pdf (accessed on 15 April 2011).

20. Stein, R.S.; Ferguson, K.C. Literature Review-Litter. A Review of Litter Studies, Attitude Survey and Other Litter-Related Literature; Final Report; Keep America Beautiful: Artesia, NM, USA, 2007; p. 76.

21. Acurio, F.; Rossin, A.; Teixeira, P.F.; Zepeda, F. Diagnóstico de la Situación del Manejo de Residuos Sólidos Municipales en América Latina y el Caribe; Serie Ambiental. No. 18; Organización Panamericana de la Salud y Banco Interamericano de Desarrollo: Washington, DC, USA, 1997; p. 165.

22. Tchobanoglous, G.; Kreith, F. Handbook of Solid Waste Management, 2nd ed.; McGraw-Hill Handbooks: New York, NY, USA, 2002; p. 16.

23. FCSHWM. The Florida Litter Study: 1996; Florida Center for Solid and Hazardous Waste Management, the Florida Legislature and Florida Department of Environmental Protection: Gainesville, FL, USA, 1999; p. 56. Available online: http://www.hinkleycenter.org/ images/stories/publications/96_florida_litter_study.pdf (accessed on 4 November 2009).

24. ENCAMS. Fly-Tipping Studio 2003; Fly Tipping Prevention Group: Wigan, UK, 2003. Available online: http://www.wolverhampton.gov.uk/NR/rdonlyres/5C07354B-3FAD-4E35-AB50-9123D24 D8D07/0/fly_tippinglaw.pdf (accessed on 7 June 2012). 
25. MSW Consultants. National Visible Litter Study; New Market: MD, USA, 2009. Available online: www.kab.org/research09 (accessed on 13 January 2010).

26. Al-Khatib, I.A.; Arafat, H.A.; Daoud, R.; Shwahneh, H. Enhaced solid waste management by understanding the effects of gender, income marital status, and religious convictions on attitudes and practices related to street littering in Nablus-Palestinian territory. Waste Manag. 2009, 29, 449-455.

27. KAB. Litter in America. Results from the Nation's Largest Litter Study; Keep America Beautiful, Inc.: Artesia, NM, USA, 2010. Available online: http://www.kab.org (accessed on 25 November 2010).

28. OCCM. Cantidad de Residuos Sólidos Colectados en Tiraderos Clandestinos en Vías Primarias, México; Observatorio Ciudadano de la Ciudad de México. Laboratorio Ciudadano de Análisis Socio-territorial, UAM-Cuajimalpa: Mexico City, Mexico, 2007. Available online: http://www.a19observatorio.org/home/?page_id=2 (accessed on: 6 September 2009).

29. Muñoz-Cadena, C.E.; Arenas-Huertero, F.E.; Ramón-Gallegos, E. Comparative analysis of the street generation of inorganic urban solid waste (RUSW) in two neighborhoods of Mexico City. Waste Manag. 2009, 29, 1005-1234.

30. Smith, E.; McDaniel, P.A. Covering their butts: Responses to the cigarette litter problem. Tob. Control 2011, doi:10.1136/tc.2010.036491.

31. Jefatura del DF. Programa Integrado Territorial para el Desarrollo Social. Coordinación de Planeación del Desarrollo Territorial de la colonia Jardín Balbuena Sur; INEGI, SEDUVI, IEDF, SSDF: Mexico City, Mexico, 2003.

32. OECD. Economically Active Population. Glossary of Statistical Terms. 2002. Available online: http://stats.oecd.org/glossary/detail.asp?ID=730 (accessed on 19 January 2012).

33. Patiño. INEGI, Biblioteca Emilio Alanís, Aguascalientes, Mexico. Personal communication, 2006. Ingreso Per cápita de las colonias M. Mixihuca y J. Balbuena Sur.

34. Barriada-Pereira, M.; González-Castro, M.J.; Muniategui-Lorenzo, S.; López-Mahía, P.; Prada-Rodríguez, D.; Fernández-Fernández, E. Organochlorine pesticides accumulation and degradation products in vegetation samples of a contaminated area in Galicia (NW Spain). Chemosphere 2005, 58, 1571-1578.

35. SEDUE. Protection Soil Contamination-Municipal Solid Residues-Determination of Generation. Norma Mexicana NMX-AA-061-1985; Secretaría de Desarrollo Urbano y Ecología, Jefatura del Departamento del Distrito Federal: Mexico City, Mexico, 1985.

36. Kerlinger, F.N.; Lee, H.B. Investigación del Comportamiento. Métodos de Investigación en Ciencias Sociales, 4th ed.; McGraw-Hill: Mexico City, Mexico, 2002.

37. Daniel, W.W. Estimación. In Bioestadística: Base Para el Análisis de las Ciencias de la Salud; Limusa Wiley: Mexico City, Mexico, 2005; pp. 150-203.

38. Recena, M.C.; Pires, D.X.; Caldas, E.D.; Pontes, E.R.J.C. Pesticides exposure in Culturama, Brazil-Knowledge, attitudes, and practices. Environ. Res. 2006, 102, 230-236.

39. Enkerlin, E.C.; Cano, G.; Garza y E. Vogel, R.A. Ciencia Ambiental y Desarrollo Sostenible; International Thomson Ed: Mexico City, Mexico, 1997. 
40. FCSHWM. The Florida Litter Study: 1996; Florida Center for Solid and Hazardous Waste Management, the Florida Legislature and Florida Department of Environmental Protection: Gainesville, FL, USA, 1999.

41. INEGI. IRIS-SCINCE 2008 ed. CD. Data from the 2005 Second Population and Housing Census.

42. MGM-Management. The City of Toronto. Street Litter Audit 2006; Citizen Focused Services B, Solid Waste Management Services Division: Toronto, CA, USA, 2006.

43. Ojeda-Benitez, S.; Lozano-Olvera, G.; Morelos, R.A.; Armijo de Vega, C. Mathematical modeling to predict residential solid waste generation. Waste Manag. 2008, 28, S7-S13.

44. Rodriguez-Salinas, M.A. Diseño de un Modelo Matemático de la Generación de Residuos Sólidos Municipales en Nicolás Romero, México; Instituto Politécnico Nacional, CIIEMAD: Mexico City, Mexico, 2004.

45. JGDF. Programa Integrado Territorial para el Desarrollo Social 2001-2003; Jefatura del Gobierno del Distrito Federal: Mexico City, Mexico, 2000.

46. PDDUDVC. Programa Delegacional de Desarrollo Urbano para la Delegación Venustiano Carranza del D.F; Gaceta del Distrito Federal (GDF): Mexico City, Mexico, 2005.

47. Rosas, I.; Salinas, E.; Martínez, L.; Eslava, C.; Cravioto, A. Bacterias en la Atmósfera. In Microbiología Ambiental; INE, Semarnat, UNAM: Mexico City, Mexico, 2004.

48. SOSPGDF. Manejo de Residuos Sólidos. Recolección, Transferencia y Selección; Secretaría de Obras y Servicios del Distrito Federal: Mexico City, Mexico, 2004.

49. Torgler, B.; García-Valiñas, M.A. Justifiability of Littering: An Empirical Investigation; Fondazione Eni Enrico Mattei, Natural Resources Management: Milan, Italy, 2008.

50. Williams, I.D.; Deakin, N. Littering of a watercourse in north-west England. Inst. Civ. Eng. 2007, ME4, 201-207. Available online: http://www.serg.soton.ac.uk/civEng2/www.civil.soton.ac.uk/ Publications/\%283078\%29\%20ME-ND-2007-muen160-201.pdf (accessed on 7 June 2012).

51. OECD. Counter-Cyclical Economic Policy; OECD Economics Department Policy Notes. No. 1; OECD: Paris, France, May 2010.

52. Beck, R.W. Literature Review-Litter. A Review of Litter Studies, Attitudes Surveys and Other Litter-Related Literature; Final Report; Keep America Beautiful: Artesia NM, USA, 2007.

53. Muñoz-Cadena, C.E. Estudio Comparativo de la Producción de Residuos Sólidos Urbanos Inorgánicos Callejeros (RSUIC) en dos Colonias de la Ciudad de México. Tesis para Obtener el Grado de Maestra en Ciencias Ambientales, Universidad Simón Bolívar, Mexico City, Mexico, 6 April 2008.

54. Curlow, R. Melbourne and Sydney Our Cleanest Cities; BIEC: Glebe, Australia. 2005.

55. Mercado, S. Obstáculos Psicológicos Para la Clasificación de Desechos Sólidos. In Reciclaje de Residuos Sólidos Municipales; Hernández, C., González, S., Eds.; Programa Universitario de Medio Ambiente (PUMA): Mexico City, Mexico, 1997; pp. 188-192.

56. Jones, M.; Pebley, A.R.; Sastry, N. Eyes on the block: Measuring urban physical disorder through in-person observation. Soc. Sci. Res. 2011, 40, 523-537.

57. ECOCE. Ecología y Compromiso Empresarial. FEMSA 2006. Available online: http://www.ecoce.org.mx/qeco.html (accessed on 11 June 2006).

58. Medina, R.J.A.; Jimenez, Y.I. Guía Para la Gestión Integral de los Residuos Sólidos Municipales; Semarnat: Mexico City, Mexico, 2001. 
59. De Kort, A.W.Y.; McCalley, T.L.; Midden, C.J.H. Persuasive Trash Cans. Activation of littering norms by design. Environ. Behav. 2008, 40, 870-891.

60. Ferrara, I. Waste Generation and Recycling. In Household Behavior and the Environment; OECD: Paris, France, 2008.

61. LDUDF. Ley de Desarrollo Urbano del D.F.; Gaceta Oficial del DF: Mexico City, Mexico, 2006.

62. AACM. Agenda Ambiental de la Ciudad de México. Programa de Medio Ambiente 2007-2012. Distrito Federal; Gaceta Oficial del Distrito Federal: Mexico City, Mexico, 2007.

(C) 2012 by the authors; licensee MDPI, Basel, Switzerland. This article is an open access article distributed under the terms and conditions of the Creative Commons Attribution license (http://creativecommons.org/licenses/by/3.0/). 